\title{
Kesalahan Penggunaan Kata Ganti Demonstratif Ko-so-a Pada Kalimat Bahasa Jepang Dalam Ujian Akhir Semester Penerjemahan Lisan
}

\author{
Irma Winingsih \\ Universitas Dian Nuswantoro \\ irma.winingsih@dsn.dinus.ac.id
}

Article History: Submitted date 2020-05-02; Accepted date; Published date

\begin{abstract}
Bunmyakushiji type of 'Ko-so-a' demontrative pronouns are words that are being used to replace word(s) or to refer word(s) or thing(s) which have said before. The Ko-so-a demonstrative pronouns have difference usage with pronoun in Indonesian language. Writer found out there are many Japanese learners in Japanese Language Department of Dian Nuswantoro University including were having difficulties to distinguish functions of each pronoun. Because of that, writer is interested in analyzing the errors made by learner when using bunmyakushiji type of demonstrative pronoun. Writer use qualitative method and analytic descriptive. The data were collected from conversations of Interpreting class's Final Exam. The result was error usage of So and A demonstrative pronouns often happened than error usage of Ko and So demonstrative pronouns.
\end{abstract}

Keywords: kosoa, error, demonstrative, understanding.

\section{Abstrak}

Kata ganti demonstratif Ko-so-a yang berfungsi kontekstual digunakan untuk merujuk atau menggantikan kata yang dituturkan sebelumnya. Penggunaannya berbeda dengan kata ganti demonstratif dalam bahasa Indonesia.Karena dalam Ujian Akhir Semester mata kuliah Penerjemahan Lisan yang merupakan percakapan antara penguji dengan mahasiswa cukup banyak ditemukan kesalahan penggunaan kata ganti ini, maka penulis tertarik untuk meneliti kesalahan tersebut. Metode yang digunakan adalah metode kualitatif dengan analisis deskriptif. Data diperoleh dari percakapan/tanya jawab dalam ujian. Hasilnya yaitu kesalahan penggunaan kata ganti demonstrative So dan A lebih banyak ditemukan dibandingkan kesalahan penggunaan kata ganti demonstratif Ko dan So.

Kata Kunci: ko-so-a, kesalahan, demonstratif, pemahaman 


\section{Pendahuluan}

Dalam pembelajaran bahasa Jepang, kata ganti demonstratif (shijidaimeishi ) seperti kore, sore are, kono, sono, ano, koko, soko, asoko, dan seterusnya yang menggunakan koso-a sudah diajarkan di awal pertemuan. Bahkan kata-kata ini merupakan pelajaran pertama dalam pembelajaran tata bahasa Jepang sehingga bagi mahasiswa. Namun ternyata ketika mengikuti mata kuliah Penerjemahan Lisan, mahasiswa tingkat empat di Program Studi Sastra Jepang Universitas Dian Nuswantoro. masih kesulitan dalam menggunakan ko-so-a ini. Dari hasil evaluasi, ditemukan kesalahan-kesalahan dalam menggunakan kata ganti tersebut. Inilah yang melatari penelitian ini dilakukan, yaitu untuk menemukan dan mendeskripsikan kesalahan penggunaan kata ganti ko-so-a dalam ujian praktik penerjemahan lisan.

Kata ganti demonstratif dalam bahasa Jepang (shijidaimeishi ), seperti 'ko (こ)' dapat dipadankan 'ini', 'so (そ) dipadankan 'itu' dan 'a (あ)' dalam bahasa Indonesia dipadankan sebagai 'itu' (dengan kondisi yang berbeda dengan "so"). Meskipun arti dari kata ganti tunjuk benda tersebut sudah diketahui, dalam kondisi tertentu seringkali muncul masalah, seperti kapan digunakan, menunjukkan hal apa, serta digunakan dalam kondisi bagaimana. Pada dasarnya shijidaimeishi yang diawali dengan ko digunakan ketika menunjuk pada benda/hal yang dekat dengan penutur, so digunakan untuk menunjuk hal/benda yang dekat dengan petutur, dan golongan a digunakan untuk menunjuk hal yang jauh baik dari penutur maupun petutur. Shijidaimeishi golongan so dan a jika diartikan ke dalam bahasa Indonesia hanya menjadi satu kata yaitu kata 'itu'.

\section{Kajian Teoretis}

Menurut KBBI (2008:603) pengertian dari kata 'itu' adalah kata ganti demonstratif benda (abstrak/riil) yang jauh. Atau dengan kata lain sangat jelas bahwa pengertian shijidaimeishi so dan $a$ 'itu' antara bahasa Indonesia dan Jepang mempunyai dasar yang berbeda. Menurut Tsuchiya (1984;49-51) shijidaimeishi adalah menunjukkan benda, arah, tempat, perkara, barang, dan sebagainya. 
Penelitian terdahulu mengenai shijidaimeishi ko-so-a dilakukan oleh Yoko Hasegawa (1997) dengan judul Demonstratives in Soliloquial Japanese dan dimuat di Proceedings of The 43rd Annual Meeting of Chicago Linguistics Society.

Menurut Hasegawa dalam soliloquy, frekuensi penggunaan shijidaimeishi ko-so-a sama dengan penggunaannya dalam percakapan biasa (yang ada lawan bicaranya). Selain Hasegawa, Saowaree W. Nakagawa (2000) juga melakukan penelitian mengenai shijidaimeishi ini dengan judul Cross-Cultural Practices A Comparison of Demonstrative Pronouns in Japanese and Thai. Hasil dari penelitian ini menyatakan bahwa pronomina demonstratif bahasa Jepang dan Thailand memiliki deep structure dan surface structure yang sama. Kreigman (2005) juga melakukan penelitian mengenai shijidaimeishi ko-so-a. Kreigman menjelaskan perbedaan mutlak penggunaan shijishi ko dengan so. Kreigman menganalisis kedua shijidaimeishi ini dengan mengacu pada fungsinya, yakni: (a) Genbashiji (penunjuk letak objek secara fisik) (b) Bunmyakushiji (kontekstual) dan (c) Kyouyuuchishikishiji (shared knowlegde). Sementara Keiko (2006) meneliti fungsi interaksional dari penggunaan shijidaimeishi ko-so-a melalui penelitiannya yang berjudul The Interactional Functions of The Japanese Demonstrative in Conversation. Keiko mengungkapkan adanya fungsi interaksi ko-so- $a$. Misalnya penggunaan $a$, menyiratkan kesepakatan dan persetujuan antara penutur dan petutur. Bahkan Keiko juga menyebutkan bahwa makna harus di shijidaimeishi dilihat bukan sebagai deskripsi yang terus terang untuk menyatakan suatu hubungan, melainkan lebih kepada pengungkapan pemahaman bersama antara penutur dan petutur (2006:492). Teori pendukung lainnya dikemukakan oleh Yuuji (2000) yang menyatakan bahwa bila hal yang dibicarakan penutur merupakan hal yang dialami bersama dengan petutur dan sudah diketahui petutur, atau diingat petutur, maka yang digunakan adalah shijidaimeishi a (diunduh dari http://lapin.ic.h.kyooto...).

Selanjutnya Yuuji juga mengemukakan teori mengenai ko-so-a (2000) dengan menyebutkan fungsi shijidaimeishi ko-so- $a$ ada tiga yaitu:

a. Genbashiji (penunjuk benda), merujuk pada letak keberadaan benda, atau orang, yang secara fisik tersentuh, teraba, terdengar langsung atau terlihat oleh penutur dan petutur.

b. Bunmyakushiji (kontekstual) merujuk benda secara kontekstual, namun benda riil/abstrak yang ditunjuk tidak hadir dalam tuturan. 
c. Kyooyuuchishikishiji (shared knowledge), yaitu berfungsi untuk menyatakan persetujuan/kesepahaman bersama.

Teori terakhir yang digunakan dalam penelitian ini adalah Teori Wilayah Informasi ini ditulis oleh Akio (1990:21) yang menyatakan bahwa antara penutur, petutur dengan informasi yang diekspresikan menggunakan kalimat, terdapat jarak psikologis yang linear. Jarak itu dibedakan menjadi "jauh" dan "dekat". Berdasarkan pernyataan tersebut, maka jarak yang terdapat di antara informasi dengan penutur dan petutur adalah "jauh" dan "dekat" yang selanjutnya akan disebut "definisi (1)". Lebih lanjut lagi ia menjelaskan bahwa yang disebut sebagai "wilayah informasi X" yaitu kumpulan informasi yang dekat dengan X berdasarkan definisi (1). Dalam hal ini, $\mathrm{X}$ dapat berupa penutur ataupun petutur. Atau dengan kata lain, apabila suatu informasi dikategorikan "dekat" dengan penutur maka informasi tersebut masuk dan berada dalam wilayah informasi penutur. Sebaliknya apabila suatu informasi dikategorikan "jauh" dari penutur, maka informasi tersebut berada di luar wilayah informasi penutur (Akio,1990:21). Menurut Akio juga, informasi dikatakan "dekat" atau masuk wilayah informasi penutur, bila:

a. Informasi didapat atau dialami sendiri oleh penutur

b. Informasi merupakan fakta pribadi mengenai kehidupan masa lalu atau mengenai barang pribadi penutur

c. Informasi berkaitan dengan rencana atau kegiatan yang telah ditetapkan penutur

d. Informasi menunjukkan fakta pribadi mengenai orang yang dekat atau akrab dengan penutur

e. Informasi berkaitan dengan rencana atau kegiatan yang telah ditetapkan oleh orang yang dekat atau akrab dengan penutur.

f. Informasi umum mengenai pekerjaan atau spesialisasi penutur

g. Informasi berkaitan dengan tempat yang yang memiliki hubungan yang erat dengan penutur

h. Informasi lain yang memiliki hubungan erat dengan penutur

Syarat-syarat di atas juga berlaku untuk petutur. Jika peran penutur di atas digantikan oleh petutur, maka berarti informasi ini dekat dengan petutur. Namun jika informasinya jauh 
dari penutur dan petutur, maka didefinisikan berada di luar wilayah informasi penutur dan petutur. Namun ada juga beberapa kasus di mana informasi dapat menjadi milik keduanya. Sebaliknya bila informasinya tidak sesuai dengan syarat-syarat yang telah disebutkan di atas, maka informasi tersebut dikategorikan jauh dari penutur dan petutur sehingga disebut berada di luar wilayah informasi keduanya.

Untuk menganalisis kesalahan penggunaan shijidaimeishi -nya, penulis menggunakan teori Ellis (1997). Dalam teorinya, Ellis mengkategorisasikan jenis kesalahan bahasa pembelajar menjadi kesalahan penghilangan (Omission), kesalahan penggunaan bentuk (Misinformation), kesalahan penempatan (Misordering).

1. Kesalahan Penghilangan (Omission)

Yaitu kesalahan karena pembelajar menghilangkan bagian yang wajib dalam ungkapan untuk memenuhi syarat gramatikal. "Teacher not here"

Kalimat di atas tidak tepat karena ada penghilangan to be (partikel) "is" dalam kalimat sehingga kalimat tersebut menjadi tidak gramatikal. Kalimat yang benar: "Teacher is not here" 'Guru tidak ada disini'

2. Kesalahan Penggunaan Bentuk (Misinformation)

Yaitu kesalahan penggunaan bentuk tata bahasa ke dalam bentuk tata bahasa yang lain. Contoh : "A man and a little boy was watching him"

Kalimat ini tidak benar karena "was" digunakan mengikuti subjek berbentuk tunggal (singular) dan "were" digunakan saat subjeknya jamak (plural). Kalimat yang benar : "A man and a little boy were watching him" 'Seorang pria dan seorang anak kecil sedang mengawasinya'

3. Kesalahan Penempatan (Misordering)

Kesalahan penempatan merupakan kesalahan menempatkan kata-kata dengan urutan yang tidak tepat. Contoh : "There they had a big surprise"

Kalimat di atas tidak benar karena adanya kesalahan penenempatan yang menyebabkan kalimat ini menjadi tidak gramatikal. Kalimat yang benar: "They had a big surprise there" 'Mereka mempunyai kejutan besar di sana'. 
Jack Richard dalam Parera (1997: 139) menyatakan bahwa sumber kesalahan seperti ini biasanya berupa :

a. Penerapan kaidah yang tidak lengkap

Pemelajar cenderung tidak lengkap menerapkan kaidah atau justru pemelajar menerapkan kaidah secara berlebihan. Pada umumnya, hal ini dikarenakan menghindari beban linguistik yang terlalu besar.

b. Generalisasi berlebih

Maksud dari generalisasi berlebih yaitu fakta dan kebiasaan pemelajar bahasa membuat bentuk-bentuk yang sama yang diketahui oleh pemelajar ke dalam bahasa target. Semua kaidah dalam bahasa tersebut disama ratakan oleh pemelajar bahasa.

c. Ketidaktahuan akan batas-batas kaidah suatu bahasa

Jenis kesalahan ini hampir sama dengan kesalahan dalam tindak generalisasi. Meskipun keduanya bertolak dari ketidaktahuan, namun generalisasi berlebih disebabkan perasaan serba tahu menempatkan sesuatu.

Sementara itu Klein (2003:79) menyebutkan bahwa dalam pemerolehan bahasa target bagi orang dewasa, sering terjadi permasalahan analisis yang terdiri dari dua komponen utama yaitu pengetahuan yang tersedia untuk pemelajar dan input dari analisis yang akan disampaikan. Dalam proses sintesis, terdapat bentuk yang berlawanan dari komponen pertama, tetapi tidak ada komponen yang dapat dibandingkan untuk input analisis, kecuali ada niat komunikasi dari si penutur. Dapat dikatakan bahwa hal ini merupakan materi dasar di mana dengan seluruh pengetahuan yang dimilikinya penutur mampu menghasilkan suatu perkataan, yang dianggap dapat dimengerti yang sesuai dengan konteks yang diberikan.

\section{Metode Penelitian}

Penelitian ini merupakan penelitian tindakan kelas dengan menganalisis kesalahan penggunaan shijidaimeishi ko-so-a. Pengumpulan data dilakukan dengan mencatat kalimat yang digunakan mahasiswa di perkuliahan Penerjemahan Lisan Bahasa Jepang di tahun ke 4. Data yang berhasil penulis temukan adalah 25 kalimat yang menggunakan shijidaimeishi ko-so- 
$a$ ini. Jumlah mahasiswa yang mengikuti ujian adalah 41 orang dari dua kelas yang pelaksanaan ujiannya dijadikan satu hari dan satu lokasi. Kalimat yang dianalisis hanya yang menggunakan shijidaimeishi ko-so-a saja. Identifikasi penggunaaan shijidaimeishi ko-so-a dilakukan dengan menggunakan kajian Pragmatik (konteks) dan Sosiolinguistik (Teori Wilayah Informasi) yang meliputi teori Takahashi, teori Yuuji dan teori wilayah informasi Akio. Hasilnya kemudian diinterpretasikan menggunakan teori Ellis untuk mengetahui jenis kesalahannya. Hasilnya kemudian dideskripsikan secara kualitatif.

\section{Hasil dan Pembahasan}

\subsection{Kesalahan penggunaan shijidaimeishi ko}

(1) Ini adalah nara sumber pembuatan gethuk Kalialang.

"Kono kata ha Kalialang no gethuk to iu tabemono wo setsumei suru hito desu."

Konteks:

Penutur memperkenalkan kepada petutur yang kebetulan adalah penutur jati bahasa Jepang yang menguji dalam Ujian Akhir Semester tersebut, bahwa orang yang saat itu di posisi yang agak jauh dari penutur adalah nara sumber pembuatan makanan Gethuk Kalialang.

Jika dilihat dari bentuknya, maka penggunaan ko dalam "kono kata" 'orang ini'menunjukkan posisi orang yang dibicarakan dekat dengan penutur, atau masuk dalam wilayah komunikasi penutur. Karena sebelumnya penutur dan nara sumber sebagai orang yang dibicarakan sudah terlibat pembicaraan, yakni saat penutur mewawancarai nara sumber tersebut, maka orang tersebut, memang masuk dalam wilayah komunikasi penutur. Di sini terjadi kesalahan penggunaan bentuk (misinformation). Alasannya adalah, dalam konteks memperkenalkan seseorang dalam bahasa Jepang kosa kata yang digunakan adalah kochira, yang merupakan bentuk ragam hormat untuk shijidaimeishi koko (di sini) atau jika dalam kalimat di atas seharusnya adalah "Kochira ha Gethuk Kalialang to iu tabemono wo setsumei suru hito desu." Konteks ujaran ini adalah mahasiswa memperkenalkan penjual sekaligus yang akan menerangkan cara pembuatan Gethuk Kalialang kepada penutur jati yang merupakan tim penguji. Pada saat memperkenalkan seseorang, seharusnya yang digunakan adalah shijidaimeishi "Kochira" bukan yang lain. Kesalahan ini diakibatkan generalisasi berlebihan yang 
menganggap bahwa bahasa Jepang dari "Ini adalah...." dapat diterjemahkan menjadi kono kata, dengan tanpa memperhatikan ungkapan yang seharusnya digunakan dalam memperkenalkan orang lain dalam bahasa Jepang. "Kochira" dapat dikatakan sebagai idiom yang tidak dapat digantikan dengan kosa kata yang lain, jika konteksnya adalah memperkenalkan orang lain. Generalisasi dengan tanpa mengindahkan konteks budayanya dapat mengakibatkan kesalahan dalam tuturan.

(2) Aturan baru mengenai Kampung Jawi sebagai wisata kuliner sudah dikeluarkan. Hal itu menjadi acuan bagi warga.

Kampung Jawi ga ryourikankou ni naru koto ni kan suru atarashii kisoku wo shirasetakara, hitobito ha kono kisoku wo mamoranaito ikemasen.

Konteks:

Penutur menjelaskan kepada petutur (Native Speaker: penguji) mengenai adanya aturan bahwa Kampung Jawi sudah ditetapkan sebagai tempat wisata kuliner di Semarang. Informasi tersebut diperoleh dari Bapak Koordinator Kampung Jawi.

Jika informasi diperoleh dari pihak ke tiga, artinya, penutur lebih dahulu mendengar dan mengetahui hal tersebut. Dengan demikian dapat dikatakan bahwa informasi tersebut adalah milik penutur/masuk dalam wilayah informasi penutur. Seperti disebutkan dalam teorinya, Akio menyebutkan bahwa jika informasi adalah milik salah satu peserta tuturan, maka shijidaimeishi yang digunakan adalah $\sim$ so. Kesalahan penggunaan $\sim$ ko dalam kono merupakan kesalahan bentuk (misinformation). Bentuk yang seharusnya digunakan adalah sono kisoku, karena penutur menginformasikan hal yang baru kepada petutur, yang mana informasi tersebut diperoleh penutur dari Koordinator Kampung Jawi. Artinya penutur sudah mengetahui/ mendengar mengenai informasi tersebut sehingga dapat dikatakan masuk wilayah komunikasi penutur. Penutur jati bahasa Jepang sebagai petutur dalam sesi ujian ini jelas belum pernah mendengar tentang adanya peraturan tersebut. Penutur yang barusaja mendapatkan informasi mengenai Kampung Jawi bermaksud menjelaskan predikat Kampung Jawi sebagai wisata kuliner baru di Semarang. Karena informasi tersebut merupakan hal yang baru diperoleh oleh petutur, maka seharusnya penutur menggunakan shijidaimeishi "sono" bukan yang lain. Penggunaan "kono" pada kalimat ini diperbolehkan jika petutur sudah pernah mendengar 
informasi tersebut atau bahkan pernah mengunjungi Kampung Jawi sebagai tempat wisata kuliner sebelum memperoleh informasi dari penutur. Kesalahan seperti ini dapat terjadi karena penutur melupakan batas-batas kaidah bahasa. Dengan tanpa pikir panjang penutur menerjemahkan peraturan ini ke dalam bahasa Jepang "kono kisoku", dengan melupakan kaidah penggunaan shijidaimeishi seperti yang diungkapkan oleh Akio. Jika penutur memahami batas-batas kaidah penggunaan shijidaimeishi maka kesalahan seperti ini dapat dihindari.

\subsection{Kesalahan penggunaan shijishi so}

(3) Kebijakan itu untuk menjaga budaya daerah.

Sonna taisaku ga chiiki no bunka wo mamoru tame desu.

\section{Konteks:}

Penutur menjelaskan kepada petutur (penguji) bahwa ada kebijakan yang terkait dengan penetapan Kampung Jawi sebagai tempat wisata kuliner di Semarang. Kebijakan itu adalah bahwa Walikota Semarang menetapkan Kampung Jawi sebagai tempat wisata kuliner agar budaya tradisional Jawa Tengah terjaga. Di Kampung Jawi banyak even dan fasilitas serta kelompok-kelompok paguyuban seni yang menjaga kelestarian seni dan budaya Jawa Tengah seperti gamelan, keroncong, rebana, dan aneka tarian khas Jawa Tengah. Informasi ini didapatkan dari hasil wawancara penutur dengan Koordinator Kampung Jawi.

Penggunaan bentuk shijidaimeishi so pada sonna menunjukkan bahwa yang dibicarakan adalah dekat dengan petutur. Namun jika berdasarkan klasifikasi dari Akio, maka secara kontekstual, penggunaan so pada sonna di sini dikarenakan informasi itu adalah milik penutur. Penutur mengetahui dan mendengar informasi itu terlebih dahulu dari Koordinator Kampung Jawi, yang artinya penuturlah yang memiliki informasi tersebut. Untuk memperkenalkan informasi baru tersebut kepada petutur, maka sudah tepat jika yang digunakan adalah shijidaimeishi $\sim$ so. Namun berdasarkan klasifikasi Yuuji, sonna digunakan dalam konotasi negatif, atau fungsinya akan menimbulkan rasa kurang enak/negatif bagi petutur. Penggunaan sonna biasanya digunakan untuk menghindari petutur, marah pada petutur, menyatakan keengganan untuk membicarakan sesuatu, atau hal lainnya yang pada intinya akan menimbulkan perasaan tidak enak bagi petutur. Padahal konteks kalimat ini hanyalah 
pernyataan dari penutur bahwa Kampung Jawi dijadikan salah satu tempat wisata yang menjaga kelestarian budaya daerah Semarang, tanpa konotasi negatif, seperti ungkapan kekesalan, menghentikan pertanyaan dari petutur, menghentikan percakapan dan sebagainya. Oleh karena itu jika "sonna" digunakan di sini, maka akan mengandung arti yang negatif bagi penguji, seperti misalnya penutur tidak ingin membicarakan mengenai informasi tersebut, penutur kesal pada penguji, penutur ingin menghindari pertanyaan mengenai informasi tersebut dan sebagainya. Kesalahan yang terjadi di sini adalah kesalahan bentuk. Hal ini disebabkan oleh penerapan kaidah yang kurang lengkap. Keterbatasan kosa kata pronomina demonstratif dalam bahasa Indonesia sedikit banyak mempengaruhi penggunaan kosa kata pronomina demonstratif bahasa Jepang. Penutur sepertinya menyamaratakan fungsi dari pronomina demonstratif $\sim$ so (sono, sore, sonna, soiu, dan seterusnya). Dengan menggunakan sonna sebagai pengganti sono, penutur kurang paham dengan perbedaan dalam fungsinya. Penutur paham dengan penggunaan so untuk merujuk pada informasi barunya, namun tidak melihat pada aspek linguistiknya, khususnya mengenai fungsi penggunaan masing-masing shijidaimeishi sono, sore, sonna dan soiu.

(4) Menurut penjual Wedang Rempah...

Sono Wedang Rempah no uru hito ni yoruto...

Konteks:

Di sini tuturan terjadi antara penutur (mahasiswa) dengan penguji (penutur jati). Penutur menjelaskan mengenai cara pembuatan Wedang Rempah khas Kampung Jawi yang enak. Informasi tersebut merupakan hasil wawancara penutur dengan penjual Wedang Rempah. Namun di sini, sebelum informasi tersebut diberikan penutur, petutur sudah sempat membeli Wedang Rempah dan berbincang-bincang dengan penjualnya. Artinya, selain penutur, petutur sudah mengenal penjual Wedang Rempah tersebut.

Jika dilihat dari bentuknya so, fungsi dari sono Wedang Rempah no uruhito merujuk pada penjual Wedang Rempah yang sudah diwawancarai penutur sebelum sesi ujian. Misal petutur belum sempat mengenal dan berbincang-bincang dengan penjual Wedang Rempah, penggunaan sono dalam sono Wedang Rempah no uruhito di sini adalah tepat, karena penutur memperkenalkan informasi baru kepada petutur. Artinya, informasi adalah milik penutur. Akan 
tetapi karena sebelumnya petutur sudah mengenal dan bahkan sudah sempat berbincangbincang dengan penjual Wedang Rempah, maka penggunaan so kurang tepat. Mengapa demikian, karena petutur juga memiliki informasi tersebut karena petutur mengalami hal yang sama dengan penutur, yaitu berkenalan, berbincang-bincang dan membeli Wedang Rempah dari nara sumber. Jika informasi secara kontekstual merupakan milik penutur dan petutur, maka shijidaimeishi yang digunakan adalah $\sim a$. Maka dalam tuturan di atas, akan lebih tepat jika yang digunakan adalah ano Wedang Rempah no uruhito. Kesalahan yang terjadi di sini adalah kesalahan penggunaan bentuk. Yang seharusnya digunakan adalah ano, bukan sono. Jika yang digunakan ano, maka menunjukkan bahwa informasi adalah milik penutur dan petutur, karena sebelum sesi ujian, keduanya telah mengenal dan bahkan sempat berbincang-bincang dengan penjual Wedang Rempah. Kesalahan ini disebabkan adanya keterbatasan kosa kata pronomina demonstratif bahasa Indonesia yang hanya memiliki dua kosa kata yakni ini dan itu. Pemahaman penggunaan kosa kata "itu" yang dapat merujuk kepada entitas yang dekat dengan petutur atau dapat juga jauh dari penutur dan petutur dengan tanpa adanya referensi mengenai wilayah komunikasi, cukup membuat bingung saat hendak dikonversikan ke dalam bahasa Jepang. Kesalahan ini cukup banyak terjadi karena mahasiswa kurang paham bahwa saat informasi sudah menjadi milik bersama antara penutur dan petutur, maka shijidaimeishi yang digunakan seharusnya adalah $\sim a$. Seperti pada situasi di atas, petutur kebetulan sudah memiliki informasi tersebut, jadi seharusnya yang digunakan adalah ano. Penyebab kesalahan ini terjadi dapat dikarenakan ketidaktahuan batas-batas kaidah suatu bahasa. Penutur menggunakan shijidaimeishi sono karena artinya yang sama dengan shijidaimeishi ano, namun tidak mencermati batas-batas penggunaannya. Penutur seharusnya memahami mengenai wilayah informasi tuturan agar terhindar dari kesalahan seperti ini.

(5) Yang tadi di atas meja adalah macam-macam bahan Wedang Rempah seperti jahe,...

Sore ha Wedang Rempah no zairyou no shurui desu. Jahe...

Konteks:

Penutur menjelaskan kepada petutur (penguji) bahwa bahan-bahan yang sebelumnya telah dilihat oleh penutur dan petutur, yang diletakkan di atas meja penjual Wedang Rempah, 
adalah bahan-bahan untuk membuat Wedang Rempah. Baik penutur dan petutur sudah mengetahui mengenai hal ini bahkan sudah melihat sendiri bahan-bahan tersebut.

Shijidaimeishi sore di sini adalah pronomina demonstratif yang merujuk pada bahanbahan untuk membuat Wedang Rempah. Kebetulan bahan-bahan tersebut sudah dilihat baik oleh penutur maupun petutur. Bahkan sebelumnya penutur dan petutur sudah mencicipi Wedang Rempah tersebut saat membelinya di tempat yang sama di mana bahan-bahan tersebut diletakkan. Jika dilihat dari sini, maka dapat disimpulkan bahwa informasi adalah milik kedua partisipan tuturan, yakni penutur dan petutur. Keduanya sudah mempunya pengalaman yang sama yakni mengenal penjual, melihat bahan-bahan dan mencicipi Wedang Rempah tersebut.

Oleh karenanya bila informasi adalah milik penutur dan petutur, maka shijidaimeishi yang digunakan seharusnya a. Dalam tuturan di atas, seharusnya "Are ha Wedang Rempah no zairyou no shurui desu. ..." Meskipun jika diterjemahkan ke bahasa Indonesia, "are" dan "sore" sama artinya yaitu: itu, namun penggunaannya dalam bahasa Jepang shijidaimeishi $\sim a$ memiliki syarat, yakni hanya digunakan jika penutur dan petutur memiliki wilayah komunikasi dari informasi tersebut.

\subsection{Kesalahan penggunaan shijishi $a$}

(6) Untuk isi nasi bakar ada 3 macam yaitu ikan peda pedes, ayam dan jamur. Nasi Bakar no naka ha iro-iro desuyo. Peda no sakana, chikin to shitake desu. Ano peda ha karai desu.

Konteks:

Penutur menjelaskan kepada petutur mengenai aneka rasa dari nasi bakar Kampung Jawi. Ada tiga rasa yakni ikan asin peda, jamur dan ayam. Penutur sudah mencicipi nasi bakar ayam dan jamur karena saat itu yang rasa ikan asin peda belum dibuat oleh si penjual. Sementara itu, karena petutur kurang suka pedas, maka hanya membeli nasi bakar ayam saja. Informasi mengenai adanya rasa ikan asin peda diperoleh saat penutur mewawancarai penjual nasi bakar sebelum sesi ujian. Kebetulan petutur yang merupakan Native Speaker bahasa Jepang tidak mengikuti sesi wawancara dengan penjual sehingga dapat dikatakan bahwa 
informasi tersebut adalah informasi baru bagi petutur. Selain itu, petutur belum pernah mendengar nama ikan peda apalagi melihat bentuknya.

Jika dilihat dari bentuknya shijidaimeishi a pada ano peda 'peda itu', menunjukkan bahwa informasi yang dirujuk mengenai peda, sudah menjadi wilayah komunikasi penutur dan petutur. Namun pada kenyataannya, hanya penutur saja yang sudah mengetahui dan mengalami pengalaman dengan informasi yang dirujuk ano tersebut. Penutur sudah mendengar informasi adanya nasi bakar rasa ikan peda yang pedas pada saat sesi wawancara dengan penjual nasi bakar Kampung Jawi tersebut. Artinya, hanya penuturlah yang memiliki informasi tersebut. Bagi petutur, informasi mengenai ikan peda, nasi bakar ikan peda, nasi bakar ikan peda yang pedas rasanya adalah informasi baru. Kesimpulannya, penggunaan shijidaimeishi ano di sini menjadi tidak tepat mengingat pemilik informasi hanya satu pihak, yakni penutur saja. Seperti kita ketahui bahwa penggunaan shijidaimeishi $\sim a$ digunakan jika pemilik wilayah komunikasi tuturan adalah penutur dan petutur sebagai partisipan tuturan. Sedangkan dari konteks di atas jelas bahwa yang memiliki informasi adalah penutur saja, yang kemudian memberitahukan informasi baru tersebut ke petutur. Kesalahan yang terjadi di sini adalah kesalahan penggunaan bentuk, yang seharusnya menggunakan shijidaimeishi so namun yang digunakan oleh penutur adalah $\sim a$. Kesalahan ini disebabkan hal yang sama dengan analisis sebelumnya, karena perbedaan penggunaan shijidaimeishi $\sim a$ dan $\sim$ so, dirasa cukup membingungkan bagi mahasiswa. Pemahaman bahwa hanya ada satu kosa kata yakni "itu" untuk mewakili shijidaimeishi so dan a dalam bahasa Jepang membuat terjadinya penggunaan yang begitu saja dengan tanpa melihat batas-batas kaidah bahasanya. Ditambah dengan pengetahuan yang kurang mengenai kaidah penggunaan kosa kata shijidaimeishi khususnya $\sim a$ dan $\sim$ so, membuat kesalahan penggunaan shijidaimeishi $\sim a$ dan $\sim$ so sering terjadi. Mahasiswa masih kesulitan dalam memilah apakah informasi tersebut sudah dimiliki penutur dan petutur, atau hanya salah satunya, apalagi dalam sesi ujian yang alokasi waktunya terbatas dan seringkali menimbulkan ketegangan sehingga waktu untuk memilah apakah informasi itu milik salah satu partisipan tutur atau milik keduanya, hampir tidak ada.

(7) Cara pembuatan gethuk yang seperti itu sepertinya sangat mudah meskipun sedikit menguras tenaga.

Ano gethuk no tsukurikata ga chotto muzukashii desuga, jikanmo kakarimasu. 
Konteks:

Penutur menjelaskan kepada petutur (penguji) bahwa pembuatan gethuk Kalialang sebetulnya sangat mudah meskipun sedikit menguras tenaga, terutama saat menumbuk singkong rebus dan mencampurnya sebagai adonan. Pada saat wawancara dengan penjual gethuk Kalialang, penutur tidak ikut hadir sehingga dapat dikatakan bahwa informasi mengenai bahan dasar dan pembuatan gethuk ini merupakan informasi baru bagi penutur. Sebelum sesi ujian dimulai, meskipun penutur sudah melihat penjual gethuk, tapi penutur tidak membelinya. Penutur hanya membeli nasi pecel, nasi bakar dan Wedang Rempah saja. Intinya, yang memliki informasi sepenuhnya adalah penutur.

Pada analisis sebelumnya shijidaimeishi $\sim a$ digunakan jika informasi yang dirujuk merupakan wilayah komunikasi milih kedua partisipan tuturan, yakni penutur dan petutur. Jadi jika di sini digunakan shijidaimeishi a maka menunjukkan bahwa informasi mengenai bahan dasar dan pembuatan Gethuk Kalialang dimiliki oleh penutur dan petutur. Padahal faktanya, karena petutur hanya melewati penjual Gethuk, tidak membelinya atau bahkan hadir dalam sesi wawancara dengan penjual gethuk, maka informasi mengenai cara pembuatan gethuk tersebut menjadi informasi baru bagi petutur. Artinya pengalaman berkenalan, berbicara dan mewawancarai penjual Gethuk hanya dimiliki oleh penutur saja. Petutur tidak memiliki pengalaman yang sama dengan penutur, meskipun sempat mencicipi Gethuk, namun petutur hanya memperolehnya dari peneliti. Pada konteks ini tidak terjadi sharedknowledge antara penutur dengan petutur. Pengalaman yang hanya dimiliki oleh salah satu peserta tuturan harus menggunakan shijidaimeishi "so", bukan "a". Oleh karenanya, penggunaan shijidaimeishi a pada ano gethuk.... Pada konteks di atas adalah kurang tepat. Kesalahan tersebut dikarenakan penutur hanya memliki pemahaman bahwa kosa kata bahasa Jepang yang menggantikan "itu" dalam bahasa Indonesia adalah shijidaimeishi $\sim a$ dan $\sim$ so. Namun kenyataannya pembedaan penggunaan kedua shijidaimeishi ini kurang dipahami secara mendalam. Keahlian untuk dapat memilah apakah informasi yang dirujuk dengan shijidaimeishi tersebut adalah milik penutur dan petutur, ataukah hanya milik salah satu partisipan tuturan saja. Penggunaan shijidaimeishi $\sim a$ dan $\sim$ so dianggap dapat saling menggantikan. Padahal menurut teori Akio jelas bahwa 
butuh pemahaman mengenai siapa pemilik wilayah komunikasi tuturan yang dirujuk dengan shijidaimeishi tersebut.

\section{Simpulan}

Dari data yang ada, kesalahan yang ditemukan umumnya adalah kesalahan penggunaan bentuk shijidaimeishi $\sim$ so dan $\sim a$. Hal tersebut dikarenakan fungsi antara shijidaimeishi $\sim$ ko dengan so tidak terlalu sulit untuk dibedakan. Perbedaan bahwa jika shijidaimeishi ko dekat dengan penutur, dan so dekat dengan petutur lebih mudah untuk dipilah dibandingkan shijidaimeishi $\sim$ so dengan $\sim$ a. Kesalahan penggunaan shijidaimeishi $\sim$ so dengan $\sim$ a di sini disebabkan oleh proses generalisasi yang dilakukan dengan tidak memahami batasan-batasan kaidah bahasa. Mahasiswa terlihat menganggap penggunaan $\sim a$ dan $\sim$ so sebagai konversi bahasa dari "itu" dalam bahasa Indonesia dapat saling menggantikan/dapat digunakan begitu saja. Padahal jelas berdasarkan teori Akio, siapakan yang menjadi pemilik wilayah informasilah yang menentukan penggunaan shijidaimeishi $\sim$ so dengan $\sim a$. Ditemukan juga kesalahan penggunaan shijidaimeishi untuk konteks memperkenalkan orang lain yang seharusnya menggunakan "kochira", dan data yang lain yakni penggunaan shijidaimeishi sonna yang tidak tepat.

\section{Referensi}

Alwi, Hasan, dkk. (1998). Tata Bahasa Baku Bahasa Indonesia. Jakarta: Departemen Pendidikan dan Kebudayaan Republik Indonesia

Hasegawa, Yoko. (1997). Demonstratives in Soliloquial Japanese. Proceedings of The 43rd Annual of Chicago Linguistics Society. USA: Chicago

Hayashi. (2004). Japanese Demonstrative Pronouns in Semantical Interpretation.( Diunduh dari http://cat.inist.fr/?aModde=afficheN8 ... ) tanggal 22 Desember 2018

Inoue, Yuuki. (2006). Kosoa Kotoba. Osaka: Osaka Otani Daigaku

Kamio, Akio. (1990). Johoo no Nawabari Riro - Gengoo no Kinooteki Bunseki. Japan: Taishuukan shooten.

Kamus Besar Bahasa Indonesia. (2008). Jakarta: Balai Pustaka

Kreigman. (2005). Nihongono Shiji diunduh dari http://cse.hit-u.ac.jp/ staf/iori/ronbun_iori/ syuron.pdf pada Juli 2015

Lee, Kyung Hwa. Shijishi no hatsuwa kinou: poraitonesu no kanten kara. Hokkaido: Hokkaido University

Levinson, Stephen C. (1991). Pragmatics. Cambridge: Cambridge University Press. 
Lyons, John. 1977. Semantics (Vol 2). Cambridge: Cambridge University Press Makoto.

Matsuo, Chiyuu. (2012). kou/sou/aa no shiji tokusei. Diakses 2 September 2013 dari http://www.gges.org/library/class1/docuclass1/soturon/Matsuo2012.pdf

Nakagawa, Saowaree W. 2012. Cross-Cultural Practices: Comparison of Demonstrative.

Pronouns in Japanese and Thai. NUCB Journal of Language, Culture, and Communication. Vol.4 No. 1. Hal 21-31 , (2004). Minnano Nihongo Shokyuu II no Bunpookaisetsu. Tokyo:Suriee Network.

Naruoka, Keiko. (2006). The Interactional Functions of the Japanese Demonstratives in Conversation. Belgium: International Pragmatics Associaton.

Saifudin, A. (2019). Deiksis Bahasa Jepang dalam Studi Linguistik Pragmatik. Japanese Research on Linguistics, Literature, and Culture 2 (1), 16-35.

Takahashi, Tarou, dkk. (2000). Nihongo no Bunpoo. Japan: Keishiki Kaisha Seibunsha

Teramura, dkk. (1998). Keesu Sutadi Niho Bunpoo. Japan: Oofuusha Takiura.

Tsuchiya, Shinichi. (1984). Ninshou Daimeishi to Yobikakeno Kotoba.Toukyou:Kokuritsu Kokugo Kenkyuujo.

Winingsih, I. (2012). Tinjauan Wilayah Komunikasi pada Penggunaan Shijishi Ko-So-A dalam Wawancara Interaktif Bahasa Jepang. LITE: Jurnal Bahasa, Sastra, dan Budaya, 8 (2), 117-134.

Winingsih, I. (2011). Analisis Deiksikal Pronomina Demonstratif KO-SO-A. LITE: Jurnal Bahasa, Sastra, dan Budaya, 7 (1), 42-51.

Yule,G. (1996). Deixis and Distance Pragmatics. Oxford: Oxford UP.

Yuuji, Toogoo. Danwa Moderu to Nihongo no Shijishi Ko.So.A. diunduh dari http://lapin.ic.h.kyoto-u.ac.jp/discourse.kosoa.pdf pada Oktober 2008. 